\title{
KANDUNGAN PROTEIN KASAR DAN SERAT KASAR PADA KULIT PISANG RAJA YANG DIFERMENTASI DENGAN Trichoderma viride DAN Bacillus subtilis SEBAGAI BAHAN BAKU PAKAN IKAN
}

\section{CRUDE PROTEIN AND FIBER CONTENT OF ROUGH OF FERMENTED ON THE KING BANANA SKINS BY Trichoderma Viride AND Bacillus Subtilis AS RAW FISH FEED}

\author{
Mohamad Yusuf, Agustono dan Dewa Ketut Meles \\ Fakultas Perikanan dan Kelautan Universitas Airlangga \\ Kampus C Mulyorejo - Surabaya, 60115 Telp. 031-5911451
}

\begin{abstract}
Utilization of fish waste as an alternative feed ingredient in the effort to increase the availability of raw materials making up rations. Banana skin is one that has the potential of agricultural waste into alternative feed ingredients, but the nutritional value contained in the banana peel is still low so we need to attempt to improve nutritional content, one of which is fermentation method using Trichoderma viride and Bacillus subtilis in order to improve crude protein and lower content of crude fiber on a banana peel. This study aims to determine the influence of Trichoderma viride on crude protein and crude fiber are fermented banana skin, know the effect of Bacillus subtilis on crude protein and crude fiber are fermented banana skin and know the effect of interaction of Trichoderma viride and Bacillus subtilis of crude protein and fiber fermented banana skin rough. This research method is to experiment with Completely Randomized Design (CRD) as a factorial experimental design. The treatments used consisted of two factors, namely the effect of Trichoderma viride (factor A) and Bacillus subtilis (factor B). Factor A consisted of three dose levels: $0 \%, 3 \%$ and $6 \%$, while factor B consists of three levels ie dose of $0 \%, 4 \%$ and $8 \%$. Each treatment combination was replicated 3 times. The results showed that the use of Trichoderma viride and Bacillus subtilis in fermentation processes plantain skin showed significant differences on crude protein and crude fiber on dry matter $(\mathrm{p}<0.05)$.
\end{abstract}

Keywords : Trichoderma viride, Bacillus subtilis, banana skin fermentation

\section{Pendahuluan}

Dewasa ini permintaan terhadap produksi perikanan budidaya guna memenuhi gizi masyarakat semakin meningkat, dengan meningkatnya produksi ikan terutama ikan budidaya maka secara otomatis akan terjadi kenaikan permintaan pakan (Hadadi dkk., 2007). Salah satu upaya untuk menghasilkan pakan yang bermutu adalah menjaga ketersediaan bahan baku baik secara kualitas maupun kuantitas, disamping itu bahan baku ini harus mudah diperoleh, tidak bersaing dengan kebutuhan manusia, ekonomis dan tersedia sepanjang waktu (Mudjiman, 2004).

Salah satu usaha dalam peningkatan produksi hasil panen ikan adalah penyediaan bahan baku pakan berkualitas yang sampai saat ini masih mengandalkan bahan baku pakan impor terutama bungkil kedelai, tepung ikan bahkan jagung sekalipun (Amri, 2007). Usaha untuk mengurangi ketergantungan terhadap impor bahan baku pakan adalah dengan mencari alternatif bahan baku yang kualitasnya cukup baik, murah, mudah didapat dan dapat menekan biaya pakan sehingga mampu meningkatkan efisiensi usaha (Hadadi dkk., 2007).

Pemanfaatan limbah sebagai bahan pakan ikan merupakan alternatif dalam upaya meningkatkan ketersediaan bahan baku penyusun ransum. Limbah mempunyai proporsi pemanfaatan yang besar dalam ransum. Bahan pakan yang sering digunakan dalam penyusunan ransum sebagian besar berasal dari limbah dan pencarian bahan pakan yang belum lazim digunakan diarahkan pada upaya penggalian potensi limbah sebagai bahan baku pakan (Anonim, 2006). Bahan baku adalah bahan yang akan digunakan untuk membuat pakan buatan. Pakan buatan adalah pakan yang dibuat oleh manusia untuk ikan peliharaan yang berasal dari berbagai macam bahan baku yang mempunyai kandungan gizi yang baik sesuai dengan kebutuhan ikan dan dalam pembuatannya sangat memperhatikan sifat serta ukuran ikan (Widiastuti, 2007).

Tanaman Pisang (Musaceaea sp) merupakan tanaman penghasil buah yang banyak terdapat di Indonesia. Buahnya banyak 
disukai untuk dikonsumsi secara langsung sebagai buah atau diolah menjadi produk konsumsi lain seperti sale pisang, kripik pisang, selai pisang, dan lain sebagainya, namun hal ini tidak diimbangi dengan pengolahan limbah dari kulit pisang yang sangat banyak jumlahnya. Limbah ini banyak terdapat di daerah-daerah yang memproduksi keripik dan sale pisang (Satria dan Ahda, 2008). Limbah ini biasanya dimanfaatkan oleh penduduk sekitar sebagai bahan pakan ternak (Macklin, 2009).

Sebagai bahan baku pakan ikan, kulit pisang masih memiliki kandungan serat kasar yang cukup tinggi 13,0\% (Satria dan Ahda, 2008). Bahan nabati umumnya memiliki kandungan serat kasar yang sulit dicerna karena memiliki dinding sel yang kuat sehingga sulit dipecahkan (Suprapti, 2005). Kulit pisang juga memiliki kandungan protein kasar yang masih rendah yakni sebesar 7,7\% (Satria dan Ahda, 2008). Salah satu upaya untuk meningkatkan kandungan nutrisi dari kulit pisang adalah dengan melakukan fermentasi secara biologis dengan menggunakan mikroba proteolitik dan mikroba selulolitik (Hidayat dkk., 2007). Mikroba proteolitik dapat menghasilkan enzim protease yang mampu mengubah protein menjadi asam amino, sedangkan enzim selulase dapat mendegradasi selulosa menjadi senyawa oligosakarida, disakarida dan monosakarida yang bersifat larut sehingga dapat dimanfaatkan sebagai sumber karbon oleh koloni mikroba untuk berkembang biak sehingga dapat meningkatkan kandungan protein yang berasal dari koloni mikroba (Anggorodi, 1994).

Trichoderma viride merupakan mikroorganisme yang mampu menghancurkan selulosa tingkat tinggi (Volk, 2004). Bacillus subtilis memiliki kemampuan untuk menghidrolisis ikatan kimia selulosa menjadi senyawa karbohidrat terlarut yang dimanfaatkan sebagai sumber energi untuk pertumbuhannya. Semakin banyak selulosa yang didegradasikan maka akan mengakibatkan penurunan serat kasar dalam bahan pakan (Graumann, 2007). Selain itu Bacillus subtilis merupakan mikroba proteolitik yang menghasilkan enzim protease yang menghidrolisis protein menjadi senyawa polipeptida, oligopeptida dan asam-asam amino. Asam-asam amino tersebut digunakan untuk sintesis protein oleh mikroba dan mikroba sendiri merupakan sumber protein sel tunggal sehingga dapat meningkatkan kandungan protein pada pakan (Halama, 1990).

Fermentasi merupakan kemajuan bioteknologi dengan memanfaatkan mikroba dan merupakan cara alternatif optimalisasi daur ulang limbah pertanian (Muis dkk, 2008). Hasil fermentasi diharapkan terjadi peningkatan terhadap kualitas bahan pakan yang akan digunakan sebagai campuran pakan ikan dan mampu meningkatkan pertumbuhan ikan (Widiastuti, 2007).

Berdasarkan latar belakang yang dikemukakan di atas, maka perlu dilakukan penelitian tentang kandungan protein dan serat kasar pada kulit pisang yang difermentasi sehingga dapat digunakan sebagai bahan baku pakan ikan.

\section{Metodologi}

Tempat dan Waktu

Penelitian ini dilaksanakan di

Laboratorium Makanan Ternak Fakultas Kedokteran Hewan Universitas Airlangga pada bulan Pebruari - Maret 2011.

Peralatan yang digunakan dalam penelitian ini meliputi : pisau, kantong plastik ukuran $5 \mathrm{~kg}$, baki, timbangan, spuit, gelas ukur, alat untuk analisis protein kasar terdiri dari : labu Kjeldhal $100 \mathrm{cc}$, pemanas labu Kjeldhal, spatula, timbangan elektrik Sartorius, gelas ukur, labu ukur $250 \mathrm{cc}$, erlenmeyer $250 \mathrm{cc}$, labu destilasi $500 \mathrm{cc}$, pendingin Lienbiegh, pipa bengkok, sumbat karet, pembakar bunsen dan kawat kasa serta alat untuk analisis serat kasar yang terdiri dari : erlenmeyer $300 \mathrm{cc}$, erlenmeyer penghisap, corong Buchner, spatula, cawan porselen, gelas ukur, timbangan analitik, oven, penangas air dan kompresor.

Bahan yang digunakan dalam penelitian ini adalah kulit pisang raja yang diperoleh dari Desa Wage, Kecamatan Taman, Kabupaten Sidoarjo. Bahan kimia untuk analisis protein kasar yang terdiri dari : Tablet Kjeldhal, $\mathrm{H}_{2} \mathrm{SO}_{4}$ pekat, $\mathrm{NaOH} 40 \%$, Asam Borat, indikator Metil-Red, Brom Cresor Green, $\mathrm{H}_{2} \mathrm{SO}_{4} \quad 0,01 \mathrm{~N}$ dan aquadest. Bahan kimia untuk analisis serat kasar terdiri dari : $\mathrm{H}_{2} \mathrm{SO}_{4} 0,3$ $\mathrm{N}, \mathrm{NaOH} 1,5 \mathrm{~N}, \mathrm{HCl} 0,3 \mathrm{~N}$, aceton dan $\mathrm{H}_{2} \mathrm{O}$ panas.

\section{Rancangan penelitian}

Penelitian ini bersifat eksperimental. Rancangan percobaan yang digunakan pada penelitian ini adalah Rancangan Acak Lengkap (RAL) Faktorial dengan ulangan sebanyak tiga kali (I, II dan III) dan terdiri atas dua faktor, yaitu pengaruh pemberian Trichoderma viride (faktor A) dan Bacillus subtilis (faktor B). Faktor A terdiri dari tiga taraf yaitu pemberian dosis sebesar $0 \%, 3 \%$ dan $6 \%$, sedangkan faktor $\mathrm{B}$ terdiri dari tiga taraf yaitu pemberian dosis sebanyak 0\%, 4\% dan 8\% dengan kepadatan $3.10^{8} / \mathrm{ml}$. Berikut ini adalah perlakuanperlakuan pada penelitian : 
Tabel 1. Rata-Rata Kandungan Protein Kasar Kulit Pisang Raja Setelah Difermentasi (Berdasarkan Bahan Kering Bebas Air).

\begin{tabular}{|c|c|c|c|}
\hline $\begin{array}{c}\text { Kode } \\
\text { Sampel }\end{array}$ & Kombinasi Perlakuan & $\begin{array}{c}\text { Kandungan } \\
\text { Protein Kasar }(\%) \\
\text { Rata-rata } \pm \mathrm{SD}\end{array}$ & $\begin{array}{c}\text { Transformasi }(\sqrt{\mathrm{y}}) \\
\text { Rata-rata } \pm \mathrm{SD}\end{array}$ \\
\hline $\mathrm{P}_{0}$ & $\mathrm{~A}_{0} \mathrm{~B}_{0}$ & $8,0630 \pm 0,2284$ & $2,8393^{\mathrm{c}} \pm 0,0401$ \\
$\mathrm{P}_{1}$ & $\mathrm{~A}_{0} \mathrm{~B}_{1}$ & $8,0442 \pm 0,5322$ & $2,8352^{\mathrm{c}} \pm 0,0946$ \\
$\mathrm{P}_{4}$ & $\mathrm{~A}_{1} \mathrm{~B}_{1}$ & $8,2948 \pm 1,1208$ & $2,8755^{\mathrm{bc}} \pm 0,1986$ \\
$\mathrm{P}_{3}$ & $\mathrm{~A}_{1} \mathrm{~B}_{0}$ & $8,5219 \pm 0,2638$ & $2,9190^{\mathrm{bc}} \pm 0,0454$ \\
$\mathrm{P}_{2}$ & $\mathrm{~A}_{0} \mathrm{~B}_{2}$ & $8,7597 \pm 0,5801$ & $2,9585^{\mathrm{abc}} \pm 0,0989$ \\
$\mathrm{P}_{5}$ & $\mathrm{~A}_{1} \mathrm{~B}_{2}$ & $8,6261 \pm 0,5699$ & $2,9359^{\mathrm{abc}} \pm 0,0969$ \\
$\mathrm{P}_{7}$ & $\mathrm{~A}_{2} \mathrm{~B}_{1}$ & $8,8878 \pm 0,6175$ & $2,9801^{\mathrm{abc}} \pm 0,1026$ \\
$\mathrm{P}_{6}$ & $\mathrm{~A}_{2} \mathrm{~B}_{0}$ & $9,2952 \pm 0,2531$ & $3,0486^{\mathrm{ab}} \pm 0,0414$ \\
$\mathrm{P}_{8}$ & $\mathrm{~A}_{2} \mathrm{~B}_{2}$ & $9,7273 \pm 0,1841$ & $3,1188^{\mathrm{a}} \pm 0,0294$ \\
\hline Superskrip yang berbeda dalam kolom yang sama menunjukkan perbedaan nyata $(\mathrm{p}<0,05)$.
\end{tabular}

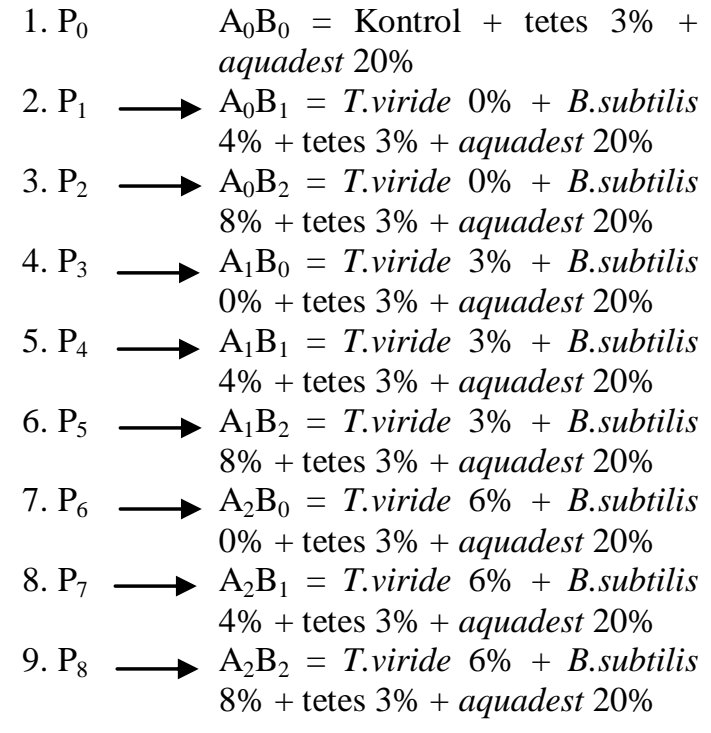

\section{Hasil dan Pembahasan}

Hasil analisis proksimat kandungan protein kasar kulit pisang raja berdasarkan bahan kering sebelum dan sesudah ditransformasi dapat dilihat pada Lampiran 6. Rata-rata kandungan protein kasar kulit pisang raja yang telah difermentasi dengan menggunakan Trichoderma viride dan Bacillus subtilis dapat dilihat pada Tabel 1. Berdasarkan analisis statistik dengan menggunakan Analisis of Varian (Lampiran 7) dapat diketahui bahwa penggunaan Trichoderma viride dan Bacillus subtilis pada proses fermentasi kulit pisang raja menunjukkan adanya perbedaan nyata terhadap kandungan protein kasar berdasarkan bahan kering $(\mathrm{p}<0,05)$.
Berdasarkan hasil Uji Jarak Berganda Duncan (Duncan's Multiple Range Test) dapat diketahui bahwa pada kode sampel $\mathrm{P}_{1}$ berbeda nyata dengan $\mathrm{P}_{6}$ dan $\mathrm{P}_{8}$ tetapi tidak berbeda nyata dengan $\mathrm{P}_{0}$ (kontrol), $\mathrm{P}_{4}, \mathrm{P}_{3}, \mathrm{P}_{2}, \mathrm{P}_{5}$ dan $\mathrm{P}_{7}$ sedangkan kode sampel $\mathrm{P}_{8}$ berbeda nyata dengan $\mathrm{P}_{3}, \mathrm{P}_{4}, \mathrm{P}_{1}$ dan $\mathrm{P}_{0}$ (kontrol) tetapi tidak berbeda nyata dengan $\mathrm{P}_{6}, \mathrm{P}_{7}, \mathrm{P}_{5}$ dan $\mathrm{P}_{2}$.

Hasil analisis proksimat kandungan serat kasar kulit pisang raja berdasarkan bahan kering sebelum dan sesudah ditransformasi dapat dilihat pada Lampiran 8. Rata-rata kandungan serat kasar kulit pisang raja yang telah difermentasi dengan menggunakan Trichoderma viride dan Bacillus subtilis dapat dilihat pada Tabel 2. Berdasarkan hasil analisis statistik dengan menggunakan Analisis of Varian (Lampiran 9) dapat diketahui bahwa penggunaan Trichoderma viride dan Bacillus subtilis pada proses fermentasi kulit pisang raja menunjukkan adanya perbedaan nyata terhadap kandungan serat kasar berdasarkan bahan kering $(\mathrm{p}<0,05)$.

Berdasarkan hasil Uji Jarak Berganda Duncan (Duncan's Multiple Range Test) dapat diketahui bahwa kode sampel $\mathrm{P}_{0}$ (kontrol) berbeda nyata dengan $\mathrm{P}_{5}, \mathrm{P}_{4}, \mathrm{P}_{8}, \mathrm{P}_{6}$ dan $\mathrm{P}_{7}$ tetapi tidak berbeda nyata dengan $\mathrm{P}_{1}, \mathrm{P}_{2}$ dan $\mathrm{P}_{3}$. Kode sampel $\mathrm{P}_{5}$ berbeda nyata dengan $\mathrm{P}_{0}$ (kontrol), $\mathrm{P}_{1}$, $\mathrm{P}_{2}, \mathrm{P}_{3}, \mathrm{P}_{8}, \mathrm{P}_{6}$ dan $\mathrm{P}_{7}$ tetapi tidak berbeda nyata dengan $\mathrm{P}_{4}$. Kode sampel $\mathrm{P}_{8}$ berbeda nyata dengan $\mathrm{P}_{0}$ (kontrol), $\mathrm{P}_{1}, \mathrm{P}_{2}, \mathrm{P}_{3}, \mathrm{P}_{5}$ dan $\mathrm{P}_{7}$ tetapi tidak berbeda nyata dengan $\mathrm{P}_{4}$ dan $\mathrm{P}_{6}$. Kode sampel $\mathrm{P}_{7}$ berbeda nyata dengan $\mathrm{P}_{0}$ (kontrol), $\mathrm{P}_{1}$, $\mathrm{P}_{2}, \mathrm{P}_{3}, \mathrm{P}_{5}, \mathrm{P}_{4}$ dan $\mathrm{P}_{8}$ tetapi tidak berbeda nyata dengan $\mathrm{P}_{6}$. 
Tabel 2. Rata-Rata Kandungan Serat Kasar Kulit Pisang Raja Setelah Difermentasi (Berdasarkan Bahan Kering Bebas Air).

\begin{tabular}{|c|c|c|c|}
\hline $\begin{array}{c}\text { Kode } \\
\text { Sampel }\end{array}$ & $\begin{array}{c}\text { Kombinasi } \\
\text { Perlakuan }\end{array}$ & $\begin{array}{c}\text { Kandungan } \\
\text { Serat Kasar }(\%) \\
\text { Rata-rata } \pm \mathrm{SD}\end{array}$ & $\begin{array}{c}\text { Transformasi }(\sqrt{\mathrm{y}}) \\
\text { Rata-rata } \pm \mathrm{SD}\end{array}$ \\
\hline $\mathrm{P}_{0}$ & $\mathrm{~A}_{0} \mathrm{~B}_{0}$ & $27,6381 \pm 1,8443$ & $5,2553^{\mathrm{a}} \pm 0,1739$ \\
$\mathrm{P}_{1}$ & $\mathrm{~A}_{0} \mathrm{~B}_{1}$ & $28,0000 \pm 1,3851$ & $5,2904^{\mathrm{a}} \pm 0,1302$ \\
$\mathrm{P}_{2}$ & $\mathrm{~A}_{0} \mathrm{~B}_{2}$ & $28,6768 \pm 1,5880$ & $5,3537^{\mathrm{a}} \pm 0,1477$ \\
$\mathrm{P}_{3}$ & $\mathrm{~A}_{1} \mathrm{~B}_{0}$ & $26,3029 \pm 2,0261$ & $5,1261^{\mathrm{a}} \pm 0,1967$ \\
$\mathrm{P}_{5}$ & $\mathrm{~A}_{1} \mathrm{~B}_{2}$ & $21,9520 \pm 0,4584$ & $4,6851^{\mathrm{b}} \pm 0,0490$ \\
$\mathrm{P}_{4}$ & $\mathrm{~A}_{1} \mathrm{~B}_{1}$ & $19,4705 \pm 1,8914$ & $4,4091^{\mathrm{bc}} \pm 0,2144$ \\
$\mathrm{P}_{8}$ & $\mathrm{~A}_{2} \mathrm{~B}_{2}$ & $18,7242 \pm 2,1959$ & $4.3220^{\mathrm{c}} \pm 0,2571$ \\
$\mathrm{P}_{6}$ & $\mathrm{~A}_{2} \mathrm{~B}_{0}$ & $17,1829 \pm 1,3231$ & $4,1432^{\text {cd }} \pm 0,1589$ \\
$\mathrm{P}_{7}$ & $\mathrm{~A}_{2} \mathrm{~B}_{1}$ & $15,1942 \pm 1,6358$ & $3,8941^{\mathrm{d}} \pm 0,2116$ \\
\hline a,b,c,
\end{tabular}

$\mathrm{P}_{1}$ dan $\mathrm{P}_{2}$ tidak berbeda nyata dengan, kode sampel $\mathrm{P}_{3} \quad \mathrm{P}_{0}$ (kontrol) sedangkan $\mathrm{P}_{6}$ berbeda nyata dengan $\mathrm{P}_{0}$ (kontrol) dan $\mathrm{P}_{3}$, kode sampel $\mathrm{P}_{4}$ dan $\mathrm{P}_{7}$ berbeda nyata dengan $\mathrm{P}_{0}$ (kontrol) sedangkan $\mathrm{P}_{4}$ berbeda nyata dengan $\mathrm{P}_{7}$ dan pada kode sampel $\mathrm{P}_{5}$ dan $\mathrm{P}_{8}$ berbeda nyata dengan $\mathrm{P}_{0}$ (kontrol) akan tetapi $\mathrm{P}_{5}$ berbeda nyata dengan $\mathrm{P}_{8}$.

Menurut Parakkasi (1995), protein kasar bukan merupakan protein yang sesungguhnya tetapi merupakan fraksi yang terbentuk dari nitrogen $(\mathrm{N})$ yang berasal dari bahan yang dianalisis. Kandungan nitrogen pada protein sekitar $16 \%$, maka jumlah protein dalam bahan dapat diperkirakan dengan menentukan jumlah $\mathrm{N}$ pada bahan tersebut dan mengalikannya dengan 6,25 (perbandingan terbalik dari $16 \%$ ), oleh sebab itu nilai yang didapat dari hasil perkalian total $\mathrm{N}$ dengan 6,25 biasa disebut protein kasar (Lestari, 2006). Berdasarkan hasil Uji Jarak Berganda Duncan (Duncan's Multiple Range Test) dapat diketahui bahwa B. subtilis bukan merupakan faktor utama yang dapat meningkatkan kandungan protein kasar kulit pisang raja, hal ini dapat dilihat pada Tabel 1. yakni kode sampel $\mathrm{P}_{1}$ dan $\mathrm{P}_{2}$ yang tidak berbeda nyata dengan $\mathrm{P}_{0}$ (kontrol). Kode sampel $\mathrm{P}_{1}$ merupakan pemberian B.subtilis sebanyak 4\% tanpa pemberian T.viride sedangkan $\mathrm{P}_{2}$ merupakan pemberian B.subtilis sebanyak $8 \%$ tanpa pemberian T.viride.

T.viride merupakan faktor utama yang dapat meningkatkan kandungan protein kasar kulit pisang raja, hal ini dapat dilihat pada Tabel 1. yakni kode sampel $P_{6}$ yang berbeda nyata dengan $\mathrm{P}_{0}$ (kontrol). $\mathrm{P}_{6}$ merupakan pemberian T.viride sebanyak $6 \%$ tanpa pemberian B.subtilis, sedangkan penambahan dosis kapang T.viride 3\% tanpa B.subtilis $\left(\mathrm{P}_{3}\right)$ diketahui belum dapat meningkatkan kandungan protein kasar secara optimal, hal ini disebabkan dosis kapang T.viride belum optimal dalam memproduksi enzim protease untuk memecah protein menjadi lebih sederhana karena jumlah mikroorganisme perombak lebih sedikit dibandingkan sumber nutrisinya sehingga menurut Wuryantoro (2000) dalam Prathiwi (2008) proses sintesis protein yang digunakan untuk pertumbuhan mikroorganisme tidak dapat berjalan normal.

Terjadi interaksi antara T.viride dan B.subtilis dalam meningkatkan kandungan protein kasar kulit pisang raja, hal ini dapat dilihat pada kode sampel $\mathrm{P}_{8}$ yang berbeda nyata dengan $\mathrm{P}_{0}$ (kontrol). Kode sampel $\mathrm{P}_{8}$ merupakan pemberian T.viride sebanyak $6 \%$ dan B.subtilis sebanyak $8 \%$, sedangkan $\mathrm{P}_{5}$ merupakan pemberian T.viride sebanyak 3\% dan B.subtilis sebanyak $8 \%$.

Menurut Nainggolan dan Adimunca (2005), serat kasar adalah serat tumbuhan yang tidak larut dalam air yang terdiri dari tiga macam yaitu selulosa, hemiselulosa dan lignin. Berdasarkan hasil Uji Jarak Berganda Duncan (Duncan's Multiple Range Test) dapat diketahui bahwa B. subtilis bukan merupakan faktor utama yang dapat menurunkan kandungan serat kasar pada kulit pisang raja, hal ini dapat dilihat pada Tabel 2. yakni kode sampel $P_{1}$ dan $P_{2}$ yang tidak berbeda nyata dengan $\mathrm{P}_{0}$ (kontrol). Kode sampel $\mathrm{P}_{1}$ merupakan pemberian B.subtilis sebanyak 4\% tanpa pemberian T.viride sedangkan $\mathrm{P}_{2}$ merupakan pemberian B.subtilis sebanyak $8 \%$ tanpa pemberian T.viride.

T.viride merupakan faktor utama yang dapat menurunkan kandungan serat kasar pada kulit pisang raja, hal ini dapat dilihat pada Tabel 2. yakni kode sampel $\mathrm{P}_{6}$ berbeda nyata dengan 
$\mathrm{P}_{0}$ (kontrol). $\mathrm{P}_{6}$ merupakan pemberian T.viride sebanyak $6 \%$ tanpa pemberian B.subtilis, sedangkan penambahan dosis kapang T.viride 3\% tanpa B.subtilis $\left(\mathrm{P}_{3}\right)$ diketahui belum dapat menurunkan kandungan serat kasar secara optimal, hal ini disebabkan dosis kapang T.viride belum optimal dalam memproduksi enzim selulase untuk memecah serat kasar menjadi lebih sederhana karena jumlah mikroorganisme perombak lebih sedikit dibandingkan sumber nutrisinya (Wood, 1985).

Terjadi interaksi antara T.viride dan B.subtilis dalam menurunkan kandungan serat kasar pada kulit pisang raja, hal ini dapat dilihat pada Tabel 2. yakni kode sampel $\mathrm{P}_{4}, \mathrm{P}_{7}, \mathrm{P}_{5}$ dan $\mathrm{P}_{8}$ yang berbeda nyata dengan $\mathrm{P}_{0}$ (kontrol). Kode sampel $\mathrm{P}_{4}$ merupakan pemberian T.viride sebanyak $3 \%$ dan B.subtilis sebanyak $4 \%$, kode sampel $\mathrm{P}_{7}$ merupakan pemberian T.viride sebanyak $6 \%$ dan B.subtilis sebanyak $4 \%$, kode sampel $\mathrm{P}_{5}$ merupakan pemberian T.viride sebanyak $3 \%$ dan B.subtilis sebanyak $8 \%$, sedangkan kode sampel $\mathrm{P}_{8}$ merupakan pemberian T.viride sebanyak $6 \%$ dan B.subtilis sebanyak $8 \%$.

\section{Kesimpulan}

Berdasarkan hasil yang diperoleh pada fermentasi kulit pisang raja menggunakan T.viride dan B.subtilis, dapat ditarik kesimpulan sebagai berikut : Penambahan T.viride berpengaruh nyata $(\mathrm{p}<0,05)$ terhadap peningkatan kandungan protein kasar dan penurunan kandungan serat kasar kulit pisang raja. Penambahan B.subtilis tidak berpengaruh nyata $(\mathrm{p}>0,05)$ terhadap peningkatan kandungan protein kasar dan penurunan kandungan serat kasar kulit pisang raja. Terdapat interaksi antara T.viride dan B.subtilis terhadap peningkatan kandungan protein kasar dan penurunan kandungan serat kasar kulit pisang raja.

Sebaiknya menggunakan kombinasi perlakuan $\mathrm{A}_{2} \mathrm{~B}_{2}$ (T.viride $6 \%+$ B.subtilis $4 \%$ ) untuk mendapatkan kenaikan protein kasar yang optimal dan $\mathrm{A}_{2} \mathrm{~B}_{1}$ (T.viride $6 \%+$ B.subtilis $4 \%$ ) untuk mendapatkan penurunan kandungan serat kasar yang lebih optimal. Dilakukan penelitian lebih lanjut yang mengarah pada aplikasi langsung terhadap pemanfaatan tepung kulit pisang raja fermentasi sebagai pakan ikan untuk melihat kualitas pakan yang meliputi kecernaan pakan dan pertumbuhan ikan.

\section{Daftar Pustaka}

Amri, M. 2007. Pengaruh Bungkil Inti Sawit Fermentasi Dalam Pakan Terhadap Pertumbuhan Ikan Mas. Universitas Bung Hatta. Padang. hal. 4-7.
Anggorodi, R. 1994. Ilmu Makanan Ternak Dasar. Gramedia Pustaka Utama. Jakarta. hal. 33-104.

Anonim. 2006. Bahan Alternatif Pakan Dari Hasil Samping Industri Pangan. Departemen kelautan dan perikanan Republik Indonesia : BBAT Jambi DITJEN Perikanan Budidaya. hal. 5-7.

Graumann, P. 2007. Bacillus: Cellular and Molecular Biology. Caister Academic press. USA. pp. 34-36.

Hadadi, A., Herry, Setyorini, A. Surahman dan E. Ridwan. 2007. Pemanfaatan Limbah Sawit Untuk Bahan Pakan Ikan. Jurnal Budidaya Air Tawar, IV (4) : (11-18).

Halama, D. 1990. Single Cell Protein. In: K.Boda (Eds). Nonconventional Feedstuffs in the Nutrition of Animal. Elsevier Science Publishing Company. Inc.New York. P. hal. 45-46.

Hidayat, N., M .C. Padaga dan S. Suhartini. 2007. Fermentasi Pengembangan Produk dan Proses Teknologi. www.hidayat. wordpress.com.8/6/2009. hal. 2-3.

Macklin, B. 2009. Pemanfaatan Limbah dari Tanaman Pisang. Fakultas Teknologi Industri Pertanian Universitas padjajaran. Bandung. http://onlinebuku.com/ 2009/01/29/pemanfaatan-limbah-daritanaman-pisang /html. hal. 1-3.

Mudjiman, A. 2004. Makanan Ikan. Ed.Refisi. Seri Agriwawasan. Penebar Swadaya. Jakarta. hal. 19-25.

Muis, A., Khairani, C., Sukarjo dan Y. P. Rahardja. 2008. Petunjuk Teknis Teknologi Pendukung Pengembangan Agribisnis Di Desa PAMI. Badan Penelitian dan Pengembangan Pertanian. Balai Pengkajian Teknologi Pertanian. Sulawesi tengah. hal. 2-3.

Nainggolan, O dan C. Adimunca. 2005. Diet Sehat Dengan Serat. Cermin Dunia Kedokteran No. 147: 43-46.

Parakkasi, A. 1995. Ilmu Nutrisi dan Makanan Ternak Ruminan. UI. Jakarta. hal. 17-19.

Prathiwi, D. A. 2008. Kandungan Protein Kasar dan Serat Kasar Tepung Isi Rumen yang Difermentasi dengan Probiotik. Skripsi. Fakultas Kedokteran Hewan. Universitas Airlangga. Surabaya. hal. 35-38.

Satria, B. dan Y. Ahda. 2008. Pengolahan Limbah Kulit Pisang Menjadi Pektin Dengan Metode Ekstraksi. Fakultas Teknik Universitas Diponegoro. Semarang. hal. 5-7.

Suprapti. 2005. Aneka Olahan Pisang. Kanisius. Yogyakarta. hal. 17-19. 
Volk, T.J. 2004. Trichoderma viride, The Dark Green Parasitic Mold And Maker Of Fungal Digested Jeans. http://botit. Botany.wisc.edu/toms_fungi/nov. pdf : 7-9.

Widiastuti, R.R. 2007. Formulasi pakan buatan dengan teknologi fermentasi pada budidaya ikan nila (oreochromis niloticus Linn). Jurusan SITH-ITB. Bandung. hal. 15-17.
Wood, T. M. 1985. Aspects of the Biochemistry of Cellulose Degradation. In. J. F. Kennedy, G. O. Phillips, D. J. Wedlock, and P. A. Williams (eds). Celllose and its Derivte; Chemistry, Biochemistry and Applications. Eleis Horwood Limeted, Jhon Wiley and Sons. New York. pp. 173-187. 